\title{
Response of Vetch Species for Different Drainage Methods on Vertisols in the Central Highland Areas of Ethiopia
}

\author{
Gezahagn Kebede $^{1}$, Fekede Feyissa ${ }^{1}$, Getnet Assefa ${ }^{2}$, Alemayehu Mengistu ${ }^{3}$, Muluneh \\ Minta $^{1}$, Tadesse Tekletsadik ${ }^{1}$, Mamaru Tesfaye ${ }^{1}$ \\ ${ }^{1}$ Holetta Agricultural Research Center, P.O.Box 31, Holetta, Ethiopia \\ ${ }^{2}$ Ethiopian Institute of Agricultural Research, P. O. Box. 2003, Addis Ababa, Ethiopia \\ ${ }^{3}$ Forage and Rangeland Scientist, Urael Branch, P.O. Box 62291, Addis Ababa, Ethiopia \\ gezk2007@yahoo.co.uk
}

\begin{abstract}
The study was conducted to evaluate the response of vicia species to different drainage methods on vertisol in the central highland areas of Ethiopia. The experiment was conducted on a split plot design using three drainage methods ( $C B, R F$ and $F B$ ) as main plot and five vicia species ( $V$. sativa, $V$. villosa, $V$. dasycarpa "Lana", V. dasycarpa "Namoi" and V. atropurpurea) as sub-plot treatments with three replicates. The combined analysis of variance showed that drainage methods, vicia species, and locations had significant differences $(P<0.05)$ for mean plant height, DM yield and seed yield. The results revealed that drainage method by year, species by location, location by year and species by year by location interaction effects were significant for at least one of the measured agronomic trait. The CB and RF showed $50.9 \%$ and $9.8 \%$ increments for plant height when compared with FB, respectively. The DM yield obtained at Ginchi showed $63.3 \%$ yield increment when compared with Киуи due to differential response of the species for temperature, soil fertility and waterlogging problem. The highest DM yield (6.46 t/ha) was recorded for CB followed by RF (4.75 t/ha) and $F B(2.89$ t/ha). The $C B$ and RF gave 123.5 and $64.4 \%$ DM yield increments when compared with FB, respectively. The highest DM yield was recorded for $V$. villosa (5.76 t/ha) followed by $V$. dasycarpa "Lana" (5.27 t/ha), V. atropurpurea (5.13 t/ha) and V. dasycarpa "Namoi" (3.89 t/ha) while V. sativa gave the lowest (3.47 t/ha) DM yield under different drainage methods. At Ginchi, 20.7\% seed yield increment was recorded when compared with Kuyu indicating that Ginchi was relatively better location for seed production of vicia species under different drainage conditions during the experimental periods. The CB and RF drainage methods gave 151.7 and $80.6 \%$ seed yield increments over the FB drainage method, respectively. The result indicated that the highest mean seed yield was recorded for $V$. atropurpurea (6.08 qt/ha) followed by $V$. dasycarpa "Lana" (5.71 qt/ha), V. villosa (5.12 qt/ha) and V. sativa (4.83 qt/ha) while V. dasycarpa "Namoi" (3.81 qt/ha) gave the lowest seed yield under different drainage methods. Generally, the selected vicia species respond differently for measured agronomic traits under different drainage methods. Therefore, $V$. villosa, $V$. dasycarpa "Lana" and V. atropurpurea showed better performance in terms of plant height, DM yield and seed yield under different drainage methods on vertisol at Kuyu and Ginchi in the central highlands of Ethiopia.
\end{abstract}

Keywords: agronomic traits, drainage methods, interaction effects, vertisol, vicia species.

\section{INTRODUCTION}

Vetch is an annual forage legume widely adapted to the highlands of Ethiopia (IAR, 1986). It grows well on the reddish brown clay soils and the black soils of the highland areas. In Ethiopia, vertisol covers $10.2 \%$ of the total soil or 12.5 million ha of which 7.6 million ha occur in highlands and is the fourth most important soil after lithosol (16.2\%), cambisol (15.3\%) and nitosol (11.8\%) (Mesfin and Jutzi, 1989). Vertisols have crucial importance for food and feed production in Ethiopia. Bull (1988) estimates that about 11.9 million ha of vertisol areas in Ethiopia are potentially arable and can produce about 12 million tons of food grain if improved management practice would be widely adopted. This soil has clay contents between 35 and $80 \%$, which largely determine their physical properties (Abiye and Ferew, 1993). Due to the high clay content, the water holding capacity is high, the infiltration rate low, and the internal drainage slow. Vertisols are structurally unstable, tend to slake easily under wet conditions and are easily compacted; on the other hand, the shrink-swell behavior of these soils enables aggregation and can regenerate a good structure after only a few cycles of wetting and drying (Wenke and Grant, 1994; Pillai and McGarry, 1999). 
During the main growing period, waterlogging is one of the major constraints for crop production in the Ethiopian highland vertisol areas. Due to high water holding capacity of this soil, aeration becomes a limiting factor for root growth and activity, unless counterbalanced by morphological and physiological adaptation of the roots. Farmers of the vertisol areas know about the adverse effects of waterlogging on crop productivity and have developed traditional methods for overcoming it. One of this methods is planting late in the rainy season, allowing only partial use of the potential growing period.

Different drainage technologies were tested at different locations to overcome the problem of impeded drainage on vertisol, but this soil respond differently in terms of productivity for various drainage methods. According to Getachew et al. (2007), the traditional management of vertisol in the Ethiopian highlands varies across locations depending on the amount and duration of the rainfall, extent of drainage problem, soil fertility, slope and farm size. Appropriate technologies to better manage vertisols are a desirable intervention in the Ethiopian highland vertisol farming systems. This can be performed by improving the surface drainage. The positive effects of surface drainage on agricultural productivity of vertisols have been widely documented. Use of different drainage methods viz, broadbed and furrow $(\mathrm{BBF})$, ridge and furrow $(\mathrm{RF})$, camber bed $(\mathrm{CB})$, flat bed $(\mathrm{FB})$ planting, post rainy season planting and soil burning can improve the productivity of vertisol.

It is evident that crop yields can be increased if excessive surface soil water is drained off and if appropriate cropping and soil fertility practices are used. Improved drainage had a significant effect on grain yield of crops, especially of wheat, whose yield increased by more than $100 \%$ compared to the yields from undrained plots (Abate et al., 1993). Fertilizer efficiency was also highest in wheat with improved drainage (Hiruy, 1986). This was further proved by the work of Ali (1992) who reported that durum wheat $\mathrm{N}$ use efficiency was higher on broad beds as compared to plants grown on flat beds. Despite much research has been done on the response of different food crops to various drainage methods, there is lack of information on response of vicia species to drainage methods. Therefore, the objective of this study was to evaluate the response in yield and yield components of selected vicia species to different drainage methods on vertisol in the central highland areas of Ethiopia.

\section{Materials AND Methods}

\section{Description of the Test Environments}

The experiment was conducted at Kuyu and Ginchi sub center during the main cropping seasons under rainfed condition. Kuyu is located at $9^{\circ} 00^{\prime} \mathrm{N}$ latitude, $38^{\circ} 30^{\prime} \mathrm{E}$ longitude at an altitude of $2400 \mathrm{~m}$ above sea level. It is $34 \mathrm{~km}$ west of Addis Ababa on the road to Ambo and is characterized with the long term (30 years) average annual rainfall of $1055.0 \mathrm{~mm}$, average relative humidity of $60.6 \%$, and average maximum and minimum air temperatures of $22.2^{\circ} \mathrm{C}$ and $6.1^{\circ} \mathrm{C}$ respectively. The rainfall is bimodal and about $70 \%$ of the precipitation falls in the period from June to September, while the remaining 30\% falls in the period from March to May (EIAR, 2005). The soil type of the area is predominantly black clay vertisol, which is characterized by an average organic matter content of $5.63 \%$, total nitrogen $0.16 \%$, pH 5.63, and available phosphorus $6.95 \mathrm{ppm}$ (Desta, 1982). Ginchi sub center is located $75 \mathrm{~km}$ west of Addis Ababa in the same road to Ambo. It is situated at $9^{\circ} 02^{\prime} \mathrm{N}$ latitude and $38^{\circ} 12^{\prime} \mathrm{E}$ longitude at an altitude of $2200 \mathrm{~m}$ above sea level, and characterized with the long term (30 years) average annual rainfall of $1095.0 \mathrm{~mm}$, average relative humidity of $58.2 \%$, and average maximum and minimum air temperatures of $24.6^{\circ} \mathrm{c}$ and $8.4^{\circ} \mathrm{c}$ respectively. The site has a bimodal rainfall pattern, with the main rain from June to September and short rain from March to May (EIAR, 2005). The soil of the area is predominately black clay vertisol with organic matter content of $1.3 \%$, total nitrogen $0.13 \%, \mathrm{pH} 6.5$ and available phosphorus $16.5 \mathrm{ppm}$ (Getachew et al., 2007).

\section{Experimental Design and Data Collection}

The experiment was conducted on black vertisol areas at Kuyu \& Ginchi during the main rainy seasons of 2012 and 2013. Tractor mounted disc ploughing and harrowing was carried out in April as a common practice for general land preparation in both testing sites. Five vicia species (i.e. V. sativa, $V$. dasycarpa "Lana", $V$. dasycarpa "Namoi", $V$. villosa and $V$. atropurpurea) were selected to evaluate their performances on three different drainage methods: CB, RF and FB. The CBs (7-11 m wide) were already constructed and used in both testing sites. On the other hand, RF was made by hand immediately before planting and maintained or renewed by hand using hand hoes when required. 
The experiment was conducted on a split plot design with drainage methods as main plot and vicia species as sub-plot with three replications. Seeds were sown in rows of $30 \mathrm{~cm}$ spacing on main plot of $4 \times 12.6 \mathrm{~m}$ and sub plot of $4 \times 2.4 \mathrm{~m}$. A spacing of $1 \mathrm{~m}$ and $1.5 \mathrm{~m}$ were used between plots and blocks respectively. The materials were sown according to their recommended seeding rate: $25 \mathrm{~kg} \mathrm{ha}^{-1}$ for $V$. villosa, V. dasycarpa and $V$. atropurpurea; $30 \mathrm{~kg} \mathrm{ha}^{-1}$ for $V$. sativa. At sowing, $100 \mathrm{~kg} \mathrm{ha}^{-1} \mathrm{DAP}$ was uniformly applied for all treatments at both locations. Two hand weeding were performed, 30 and 60 days after emergence in both years. Agronomic parameters such as plant height, herbage yield and seed yield of vicia species were recorded for analysis. These samples were made from the interior rows. Plant height was measured using a steel tape from the ground level to the highest leaf at forage harvesting stage. For plant height determination, mean height of three randomly selected plants was recorded for each sub plot. At 50\% flowering stage, plants were clipped from interior rows at $5 \mathrm{~cm}$ above the ground level to determine the biomass yield. Fresh biomass yield weight was recorded from each sub plot in the field and $500 \mathrm{~g}$ samples were taken to the laboratory. Each sub plot sample was weighed to determine fresh weight using a sensitive table balance and then oven dried for 24 hours at $105^{\circ} \mathrm{C}$ for herbage DM yield determination. Seed samples were taken from each sub plot to determine the seed yield performance of the species. In general, appropriate agronomic managements were applied on the right time to improve the yield performance of vicia species per unit area.

\section{Statistical Analysis}

The data were subjected to analysis of variance using the GLM procedure of SAS statistical software package. Data were combined over years and locations and total variability for each measured trait was quantified using pooled analysis of variance over years and locations based on the following model: $\mathrm{T}_{i j k l m}=\mu+\mathrm{Y}_{i}+\mathrm{L}_{j}+\mathrm{R}(\mathrm{YL})_{k i j}+\mathrm{D}_{l}+\mathrm{YD}_{i l}+\mathrm{LD}_{j l}+\mathrm{YLD}_{i j l}+\mathrm{R}(\mathrm{YLD})_{k i j l}+\mathrm{S}_{m}+\mathrm{YS}_{i m}+\mathrm{LS}_{j m}+$ $\mathrm{YLS}_{i j m}+\mathrm{DS}_{l m}+\mathrm{YDS}_{i l m}+\mathrm{LDS}_{j l m}+\mathrm{YLDS}_{i j l m}+\mathrm{e}_{i j k l m}$ where $\mathrm{T}_{i j k l}$ is total observation, $\mu=$ grand mean, $\mathrm{Y}_{i}$ $=$ effect of the $i$ th year, $\mathrm{L}_{\mathrm{j}}$ is effect of jth location, $\mathrm{R}(\mathrm{YL})_{k i j}$ is effect of $k$ th replication within $i$ th year and $j$ th location, $\mathrm{D}_{l}$ is effect of $l$ th drainage method, $\mathrm{S}_{m}$ is effect of the $m$ th species, YD, LD, YLD, YS, $L S, Y L S, D S, Y D S, L D S$ and $Y L D S$ are the interactions and $\mathrm{R}(\mathrm{YLD})_{k i j l}$ and $\mathrm{e}_{i j k l m}$ are the variations due to random error for main and sub-plots, respectively. Significance of the year and location effects were tested against the $\mathrm{R}(\mathrm{YL})$ mean square as the error term and the $D, Y D, L D$ and $Y L D$ effects tested against the R(YLD) mean square as an error term. All other effects were tested against the residual. Means for the main effects were separated using the means statement with the LSD at 5\% significance level. When the interaction effects were significant, the LSMEANS statement using the PDIFF of the GLM procedure was used to determine the significance of simple effects.

\section{RESULTS AND DISCUSSION}

\section{Combined Analysis of Variance}

The combined analysis of variance indicated that drainage methods, vicia species, and locations had significant differences for mean plant height, DM yield and seed yield performance (Table 1). However, year showed differences $(\mathrm{P}<0.01)$ for only DM yield. When genotypes performance is tested at several environments, the rankings usually differ since differences in the environment may produce different effect on specific genotypes (Caccarelli, 1997; Gemechu, 2012). Genotype by environment interaction reflects differences in adaptation and can be enhanced by selecting for specific adaptation or minimized by selecting for broad adaptation (Adjei et al., 2010). Therefore, multi-location evaluation of genotypes provides useful information for this broader or specific recommendation (Crossa, 1990).

Table 1. Combined analysis of variance for quantitative traits of vicia species under different drainage methods

\begin{tabular}{|l|l|l|l|}
\hline Sources of variation & Plant height $(\mathrm{cm})$ & DM yield $(\mathrm{t} / \mathrm{ha})$ & Seed yield $(\mathrm{qt} / \mathrm{ha})$ \\
\hline Drainage (DR) & $*$ & $* *$ & $* *$ \\
\hline Species (SP) & $* * *$ & $* *$ & $* *$ \\
\hline Location (L) & $*$ & $* *$ & $*$ \\
\hline Year (Y) & NS & $* *$ & NS \\
\hline DR*Y & NS & $*$ & $*$ \\
\hline SP*L & $*$ & $*$ & $*$ \\
\hline $\mathrm{L}^{*} \mathrm{Y}$ & $* * *$ & $* *$ & NS \\
\hline SP*Y*L & NS & NS & $*$ \\
\hline
\end{tabular}

$*=\mathrm{P}<0.05, * *=\mathrm{P}<0.01, * * *=\mathrm{P}<0.001, \mathrm{NS}=$ non-significant, All other possible interaction effects were not significant. 


\section{Main and Interaction Effects on Plant Height}

The year and location effects on plant height of vicia species grown under different drainage methods are indicated in Table 2. The results indicated that mean plant height of vicia species was not different $(\mathrm{P}>0.05)$ between the two experimental years. However, higher mean plant height was obtained in 2012 cropping season. Plant height was not significantly $(\mathrm{P}>0.05)$ affected by years indicating consistency of genotypes performance in both years due to similar growing conditions (rainfall, humidity, temperature etc.) between the experimental years. On the other hand, plant height was different $(\mathrm{P}<0.05)$ between the two experimental locations. The highest mean plant $(115.6 \mathrm{~cm})$ was recorded at Ginchi while at Kuyu the mean plant height was $80.0 \mathrm{~cm}$. Effect of drainage methods on mean plant height of five vicia species and mean plant height of each species combined under different drainage methods are presented in Table 3. The results showed that plant height of vicia species significantly affected $(\mathrm{P}<0.05)$ by drainage methods. The highest mean plant height was recorded in $\mathrm{CB}$ followed by $\mathrm{RF}$ and $\mathrm{FB}$. The $\mathrm{CB}$ and $\mathrm{RF}$ showed $50.9 \%$ and $9.8 \%$ increments for plant height when both were compared with FB. Similarly, CB gave $37.4 \%$ increment for plant height over the RF drainage method. The species mean plant height combined under different drainage methods also varied significantly $(\mathrm{P}<0.05)$. The results revealed that the highest mean plant height was recorded for Vicia villosa $(120.8 \mathrm{~cm})$ followed by $V$. dasycarpa "Lana" $(107.3 \mathrm{~cm}), V$. atropurpurea $(105.2 \mathrm{~cm})$ and $V$. dasycarpa "Namoi" $(99.2 \mathrm{~cm})$ while the lowest $(56.5 \mathrm{~cm})$ recorded for $V$. sativa indicating differential response of the species for waterlogging problem on vertisol. Plant height is one of the important agronomic traits affected by variation in genetic, soil fertility, climate and agronomic management (Kebede et al., 2016).

Table 2. Plant height (cm) of vicia species under different drainage methods over years and locations

\begin{tabular}{|l|l|l|l|l|}
\hline SN & Year & Plant height $(\mathrm{cm})$ & Location & Plant height $(\mathrm{cm})$ \\
\hline 1 & 2012 & 98.5 & Kuyu & $80.0^{\mathrm{b}}$ \\
\hline 2 & 2013 & 97.0 & Ginchi & $115.6^{\mathrm{a}}$ \\
\hline & P-value & $\mathbf{0 . 7 9 1 9}$ & P-value & $\mathbf{0 . 0 1 9 2}$ \\
\hline
\end{tabular}

Different superscript letters in the same column represents significant differences $(\mathrm{P}<0.05)$.

Table 3. Effect of drainage methods on plant height $(\mathrm{cm})$ of vicia species and response of the species for plant height under different drainage methods

\begin{tabular}{|l|l|l|l|l|l|}
\hline SN & Drainage method & Plant height $(\mathrm{cm})$ & SN & Species & Plant height $(\mathrm{cm})$ \\
\hline 1 & Camber bed & $122.7^{\text {a }}$ & 1 & Vicia sativa & $56.5^{\text {d }}$ \\
\hline 2 & Ridges and furrows & $89.3^{\mathrm{b}}$ & 2 & V. villosa & $120.8^{\mathrm{a}}$ \\
\hline 3 & Flat bed & $81.3^{\mathrm{c}}$ & 3 & V. dasycarpa "Lana" & $107.3^{\mathrm{b}}$ \\
\hline & P-value & $\mathbf{0 . 0 3 7 5}$ & 4 & V. dasycarpa "Namoi" & $99.2^{\mathrm{c}}$ \\
\hline & & & 5 & V. atropurpurea & $105.2^{\mathrm{bc}}$ \\
\hline & & & & P-value & $\mathbf{0 . 0 0 0 1}$ \\
\hline
\end{tabular}

Different superscript letters in the same column represents significant differences $(\mathrm{P}<0.05)$.

The year by location interaction effects for mean plant height of vicia species is indicated in Figure 1. The results showed that the interaction effects varied significantly $(\mathrm{P}<0.05)$ for plant height. The highest and significant $(\mathrm{P}<0.05)$ mean plant height was recorded at Ginchi followed by Kuyu in 2013 cropping season. On the other hand, higher plant height was recorded at Kuyu followed by Ginchi in 2012. This crossover indicated a change in the plant height ranking order at both locations in the two experimental years.

Species by location interaction effects for mean plant height is given in Figure 2. The results indicated that species by location interaction effects varied significantly $(\mathrm{P}<0.05)$ for mean plant height. All vicia species gave higher mean plant height at Ginchi when compared with Kuyu, but no rank order changes. This interaction effect was found to be significant $(\mathrm{P}<0.05)$ for all vicia species except for $V$. sativa. Genotype by environment interaction refers to the differential responses of different genotypes across a range of environments (Kang, 2004). In breeding programs, genotype by environment interaction cause many difficulties, whereas the environmental factors such as temperature and waterlogging stress affect the performance of genotypes. Consequently, multi-environment trials are widely used by plant breeders to evaluate the relative performance of genotypes for target environments (Delacy et al., 1996). If genotypes perform consistently across stressed and favorable environments, breeders may be able to efficiently evaluate genotypes in the favorable environment for both the favorable and stressed environments (Gemechu et al., 2001). 


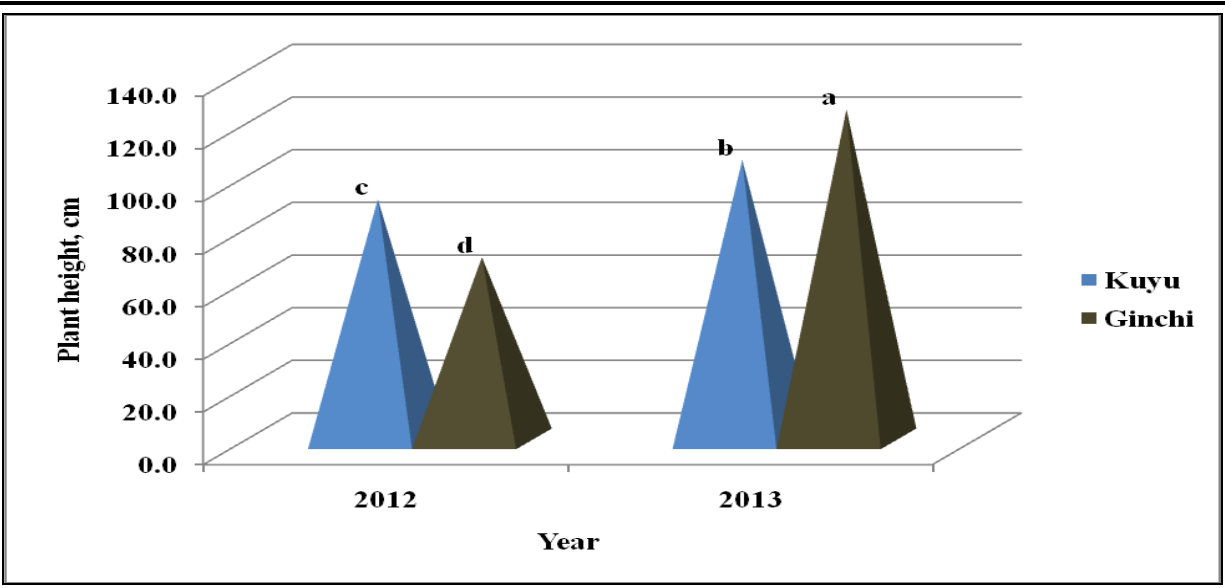

Figure 1. Year by location interaction for plant height of vicia species

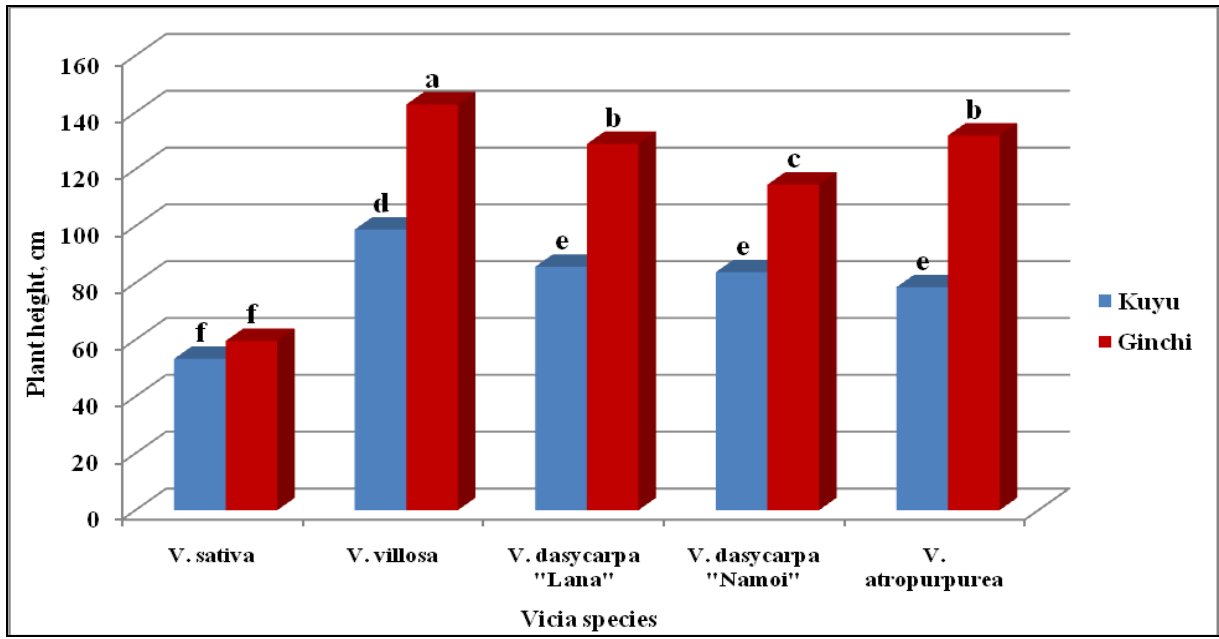

Figure 2. Species by location interaction for plant height of vicia species

\section{Main and Interaction Effects on Herbage Yield}

The DM yield response of vicia species under different drainage methods in both years and locations is presented in Table 4. DM yield of vicia species under different drainage methods was different $(\mathrm{P}<0.05)$ between the two years. Accordingly, the highest DM yield mean $(5.22 \mathrm{t} / \mathrm{ha})$ was recorded in 2012 cropping season. Also, DM yield was significantly affected $(\mathrm{P}<0.05)$ by locations. Ginchi had higher DM yield (5.83 t/ha, mean) when compared with Kuyu. The DM yield obtained at Ginchi showed $63.3 \%$ yield increment when compared with Kuyu due to differential response of the species for temperature, soil fertility and waterlogging problem. Effect of drainage methods on mean DM yield of five vicia species and mean DM yield of each species combined under different drainage methods are presented in Table 5. DM yield was significantly affected $(\mathrm{P}<0.05)$ by different drainage methods. The highest DM yield (6.46 t/ha) was recorded for CB followed by RF (4.75 t/ha) and FB (2.89 t/ha). The CB and RF were 123.5 and $64.4 \%$ DM yield higher when compared with FB respectively. Moreover, CB gave 36.0\% DM yield increment when compared with RF. The tested vicia species respond differently $(\mathrm{P}<0.05)$ for mean $\mathrm{DM}$ yield combined under different drainage methods. The highest DM yield was recorded for Vicia villosa $(5.76 \mathrm{t} / \mathrm{ha})$ followed by $V$. dasycarpa "Lana" (5.27 t/ha), V. atropurpurea (5.13 t/ha) and $V$. dasycarpa "Namoi" (3.89 t/ha) while $V$. sativa gave the lowest (3.47 t/ha) DM yield. Getnet and Ledin (2001) reported that soil type was found to be the most important factor affecting biomass yield and hence herbage production on the well drained red soil was almost double compared to the black soil. Waterlogging due to the impervious nature of the soil and poor drainage are predominant problems to increased production on these soils (Getachew et al., 1993; Efrem et al., 1996). The severity of the constraint varies from area to area depending on the clay content of the soil, rainfall and soil temperature which also depends on the moisture content of the soil. However, Getachew et al. (1988, 1993), indicated that crop yields can be improved through specific land preparation techniques. Several authors reported increase yields of some crops grown on vertisols due to the use of the BBF as compared to the FB (Abiye et al., 1995; Haque et al., 
1996; Muhamed- Saleem and Abiye, 1996). The same authors suggest that the improvement in surface drainage and yield was spectacular during the excessive rainy years. According to Gemechu et al. (2001), the trials under FB conditions suffered $20-50 \%$ yield reduction as compared to BBF. The same authors indicated that with the improvement of drainage conditions, the crop yield increases in $59.2 \%$ and $64.9 \%$ for local and improved cultivars.

Table 4. DM yield (t/ha) response of vicia species for different drainage methods over years and locations

\begin{tabular}{|l|l|l|l|l|}
\hline SN & Year & DM yield (t/ha) & Location & DM yield (t/ha) \\
\hline 1 & 2012 & $5.22^{\mathrm{a}}$ & Kuyu & $3.57^{\mathrm{b}}$ \\
\hline 2 & 2013 & $4.18^{\mathrm{b}}$ & Ginchi & $5.83^{\mathrm{a}}$ \\
\hline & P-value & $\mathbf{0 . 0 1 5 1}$ & P-value & $\mathbf{0 . 0 0 3 3}$ \\
\hline
\end{tabular}

Different superscript letters in the same column represents significant differences $(\mathrm{P}<0.05)$

The year by location interaction affects $(\mathrm{P}<0.05)$ for $\mathrm{DM}$ yield of vicia species as indicated in Figure 3. The two locations showed non-significant difference $(\mathrm{P}>0.05)$ for $\mathrm{DM}$ yield in 2013 but varied significantly $(\mathrm{P}<0.05)$ in 2012. Accordingly, the highest DM yield was recorded at Ginchi in 2013 while Kuyu gave the highest DM yield in 2012 indicating a change in DM yield ranking order at both locations in the two experimental years.

Drainage by year interaction effects for $\mathrm{DM}$ yield was found to be significant $(\mathrm{P}<0.05)$ as indicated in Figure 4. DM yield obtained from $\mathrm{CB}$ and RF were affected by years but no differences were observed on FB between the two years. CB and RF gave the highest and significant DM yield in 2012, although FB gave the highest DM yield in 2013. Species by location interaction effects for DM yield different $(\mathrm{P}<0.05)$ as indicated in Figure 5. The highest DM yield was recorded at Ginchi for all vicia species except Vicia dasycarpa "Namoi" which gave better yield at Kuyu. Species response for DM yield varied significantly between the two locations except Vicia dasycarpa "Namoi". In general, Vicia villosa, $V$. dasycarpa "Lana" and $V$. atropurpurea gave higher DM yield under different drainage methods at Ginchi. Similarly, Vicia villosa, V. dasycarpa "Lana" V. dasycarpa "Namoi" gave higher DM yield at Kuyu indicating that species respond differently under different environmental conditions.

Table 5. Effect of drainage methods on DM yield $(t / h a)$ and response of vicia species for DM yield under different drainage methods

\begin{tabular}{|l|l|l|l|l|l|}
\hline SN & Drainage method & DM yield (t/ha) & SN & Species & DM yield (cm) \\
\hline 1 & Camber bed & $6.46^{\mathrm{a}}$ & 1 & Vicia sativa & $3.47^{\mathrm{b}}$ \\
\hline 2 & Ridges and furrows & $4.75^{\mathrm{b}}$ & 2 & V. villosa & $5.76^{\mathrm{a}}$ \\
\hline 3 & Flat bed & $2.89^{\mathrm{c}}$ & 3 & V. dasycarpa "Lana" & $5.27^{\mathrm{a}}$ \\
\hline & P-value & $\mathbf{0 . 0 0 3 9}$ & 4 & V. dasycarpa "Namoi" & $3.89^{\mathrm{b}}$ \\
\hline & & & 5 & V. atropurpurea & $5.13^{\mathrm{a}}$ \\
\hline & & & & P-value & $\mathbf{0 . 0 0 6 9}$ \\
\hline
\end{tabular}

Different superscript letters in the same column represents significant differences $(\mathrm{P}<0.05)$

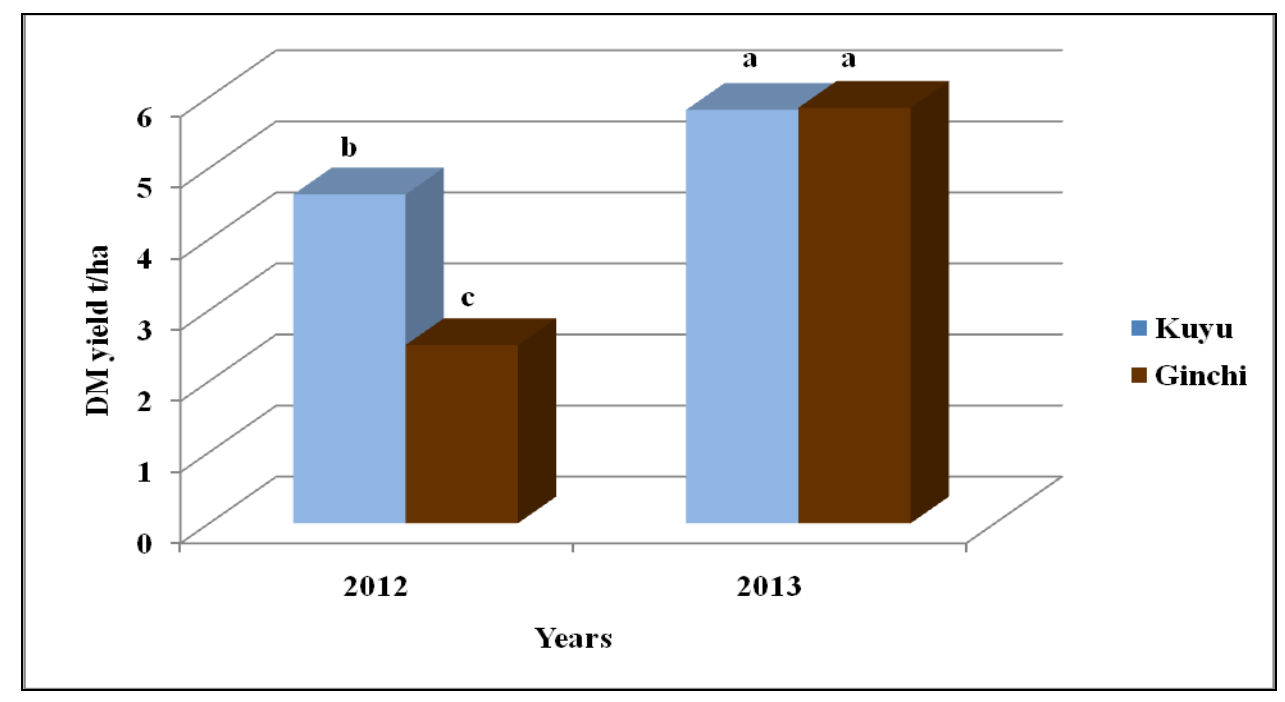

Figure 3. Year by location interaction for DM yield of vicia species 


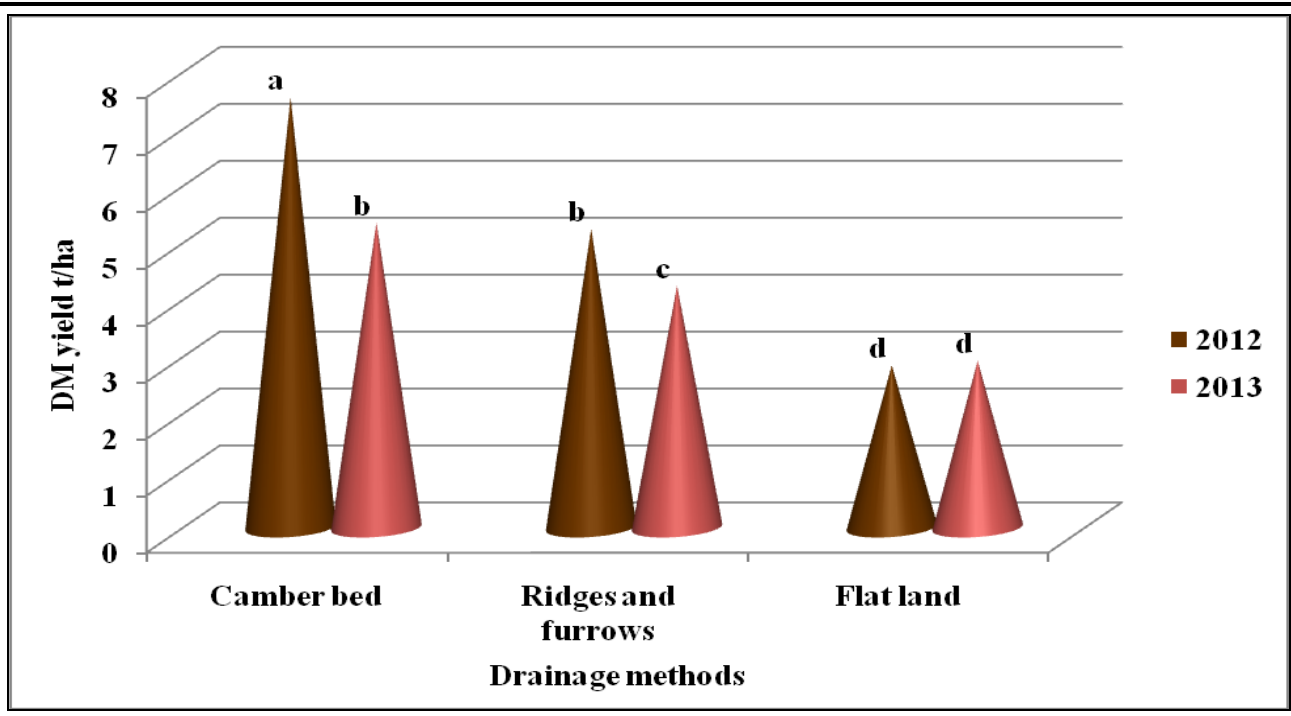

Figure 4. Drainage by year interaction for DM yield of vicia species

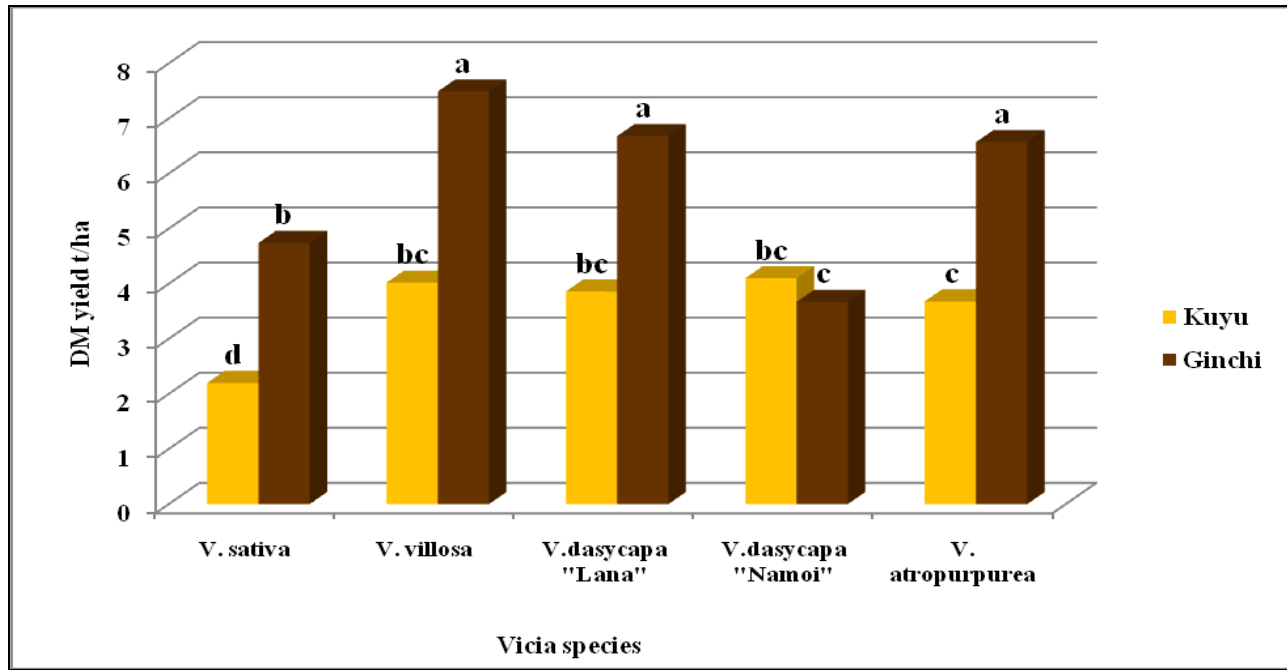

Figure 5. Species by location interaction for DM yield of vicia species

\section{Main and Interaction Effects on Seed Yield}

The seed yield performance of vicia species under different drainage methods in both years and locations is indicated in Table 6 . The results showed that seed yield was not significantly affected $(\mathrm{P}>0.05)$ by experimental years, however, the variation was significant for locations. The highest seed yield was recorded in 2012 (5.21 qt/ha) cropping season and at Ginchi (5.59 qt/ha) location when compared with other experimental year and location. At Ginchi, $20.7 \%$ seed yield increment was recorded when compared with Kuyu indicating that Ginchi was relatively better location for seed production of vicia species during the experimental periods. Effect of drainage methods on seed yield of vicia species and their response for seed yield under different drainage methods affected significantly $(\mathrm{P}<0.05)$ as indicated in Table 7 . The highest seed yield was recorded for $\mathrm{CB}(7.25 \mathrm{qt} / \mathrm{ha})$ followed by RF (5.20 qt/ha) while FB (2.88 qt/ha) gave the lowest seed yield. The CB and RF drainage methods gave 151.7 and $80.6 \%$ seed yield increments over the FB, respectively. Similarly, the CB drainage method gave $39.4 \%$ seed yield increments when compared with RF drainage method. This indicates that the use of appropriate surface drainage methods contributes to seed yield increments of vicia species under waterlogged conditions.

The seed yield performance of vicia species also varied significantly $(\mathrm{P}<0.05)$ under different drainage methods. The result indicated that the highest mean seed yield was recorded for $V$. atropurpurea (6.08 qt/ha) followed by $V$. dasycarpa "Lana" (5.71 qt/ha), $V$. villosa $(5.12 \mathrm{qt} / \mathrm{ha})$ and $V$. sativa (4.83 qt/ha) while $V$. dasycarpa "Namoi" (3.81 qt/ha) gave the lowest seed yield. Experimental findings also showed that planting chickpea, lentil and faba bean on BBF resulted in grain yield increments compared to un-drained FB conditions (Getachew and Amare, 2004). Mean grain yields of 


\section{Gezahagn Kebede et al.}

chick pea on BBF and RF increased by 59 and $46 \%$ (Getachew et al., 2007) and its grain and straw yield increments of 106 and 78\% occurred under BBF compared to FB (Abate et al., 1993). According to Gemechu and Musa (2002) findings, reductions under FB were 19\% for number of pods/plant, $4 \%$ and $1 \%$ for number of seeds/pod and 1000 seed weight, respectively, and $18 \%$ for grain yield. This may indicate that a significant portion of yield reduction under flat bed conditions was attributed to the sensitivity of number of pods/plant to waterlogging (Gemechu and Musa, 2002). This is in agreement with the general trend that genotypes normally better express their genetic potential under favorable environments as compared to the stressed ones (Singh, 1990; Simmonds, 1991; Banziger and Edmeades, 1997). Our results showed that, on average, drainage increased seed yield by $45 \%$ compared with the FB system.

Table 6. Seed yield (qt/ha) of vicia species under different drainage methods over years and locations

\begin{tabular}{|l|l|l|l|l|}
\hline SN & Year & Seed yield (qt/ha) & Location & Seed yield (qt/ha) \\
\hline 1 & 2012 & 5.21 & Kuyu & $4.63^{\mathrm{b}}$ \\
\hline 2 & 2013 & 5.00 & Ginchi & $5.59^{\mathrm{a}}$ \\
\hline & P-value & $\mathbf{0 . 2 2 6 0}$ & P-value & $\mathbf{0 . 0 1 5 6}$ \\
\hline
\end{tabular}

Different superscript letters in the same column represents significant differences $(\mathrm{P}<0.05)$

Table 7. Effect of drainage methods on seed yield (qt/ha) and response of vicia species for seed yield under different drainage methods

\begin{tabular}{|c|c|c|c|c|c|}
\hline $\mathrm{SN}$ & Drainage method & Seed yield (qt/ha) & $\mathrm{SN}$ & Species & Seed yield (qt/ha) \\
\hline 1 & Camber bed & $7.25^{\mathrm{a}}$ & 1 & Vicia sativa & $4.83^{\mathrm{c}}$ \\
\hline 2 & Ridges and furrows & $5.20^{b}$ & 2 & V. villosa & $5.12^{\mathrm{bc}}$ \\
\hline 3 & Flat bed & $2.88^{c}$ & 3 & V. dasycarpa "Lana" & $5.71^{\mathrm{ab}}$ \\
\hline & P-value & 0.0023 & 4 & V. dasycarpa "Namoi" & $3.81^{\mathrm{d}}$ \\
\hline & & & 5 & V. atropurpurea & $6.08^{\mathrm{a}}$ \\
\hline & & & & P-value & 0.0045 \\
\hline
\end{tabular}

Different superscript letters in the same column represents significant differences $(\mathrm{P}<0.05)$;

$1 \mathrm{qt}=100 \mathrm{~kg}$

Drainage by year interaction effects for seed yield of vicia species varied significantly $(\mathrm{P}<0.05)$ as indicated in Figure 6. Significant interactions were observed between the two experimental years under $\mathrm{CB}$ drainage method while no differences were observed between the two years under RF and FB drainage methods. The highest seed yield was recorded under CB drainage method in 2012 when compared with 2013, however, the remaining two drainage methods gave the highest seed yield in 2013 when compared with 2012. Species by location interaction effects for seed yield of vicia species varied significantly $(\mathrm{P}<0.05)$ as indicated in Figure 7.

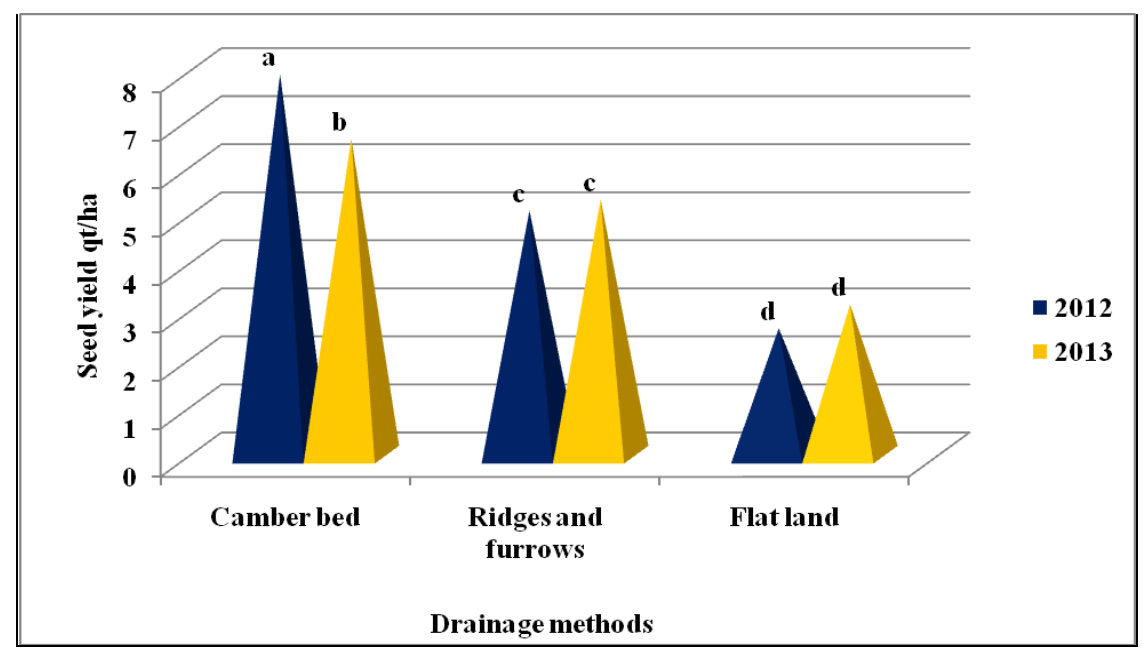

Figure 6. Drainage by year interaction for seed yield of vicia species

All species showed significant variation $(\mathrm{P}<0.05)$ between the two locations except for $V$. atropurpurea. The highest seed yield recorded at Ginchi was for $V$. atropurpurea followed by $V$. villosa and $V$. dasycarpa "Lana", however, at Kuyu the highest seed yield was obtained from $V$. atropurpurea followed by $V$. dasycarpa "Lana" and V. dasycarpa "Namoi". According to Getachew 
and Woldeyesus (2012) findings, the highly significant drainage method by variety interaction for seed yield could be due to the greater yield of improved varieties under improved drainage conditions compared with FB conditions. These results confirm the often claimed better performance of modern varieties under optimal management conditions but not under stress conditions (Sinebo, 2005).

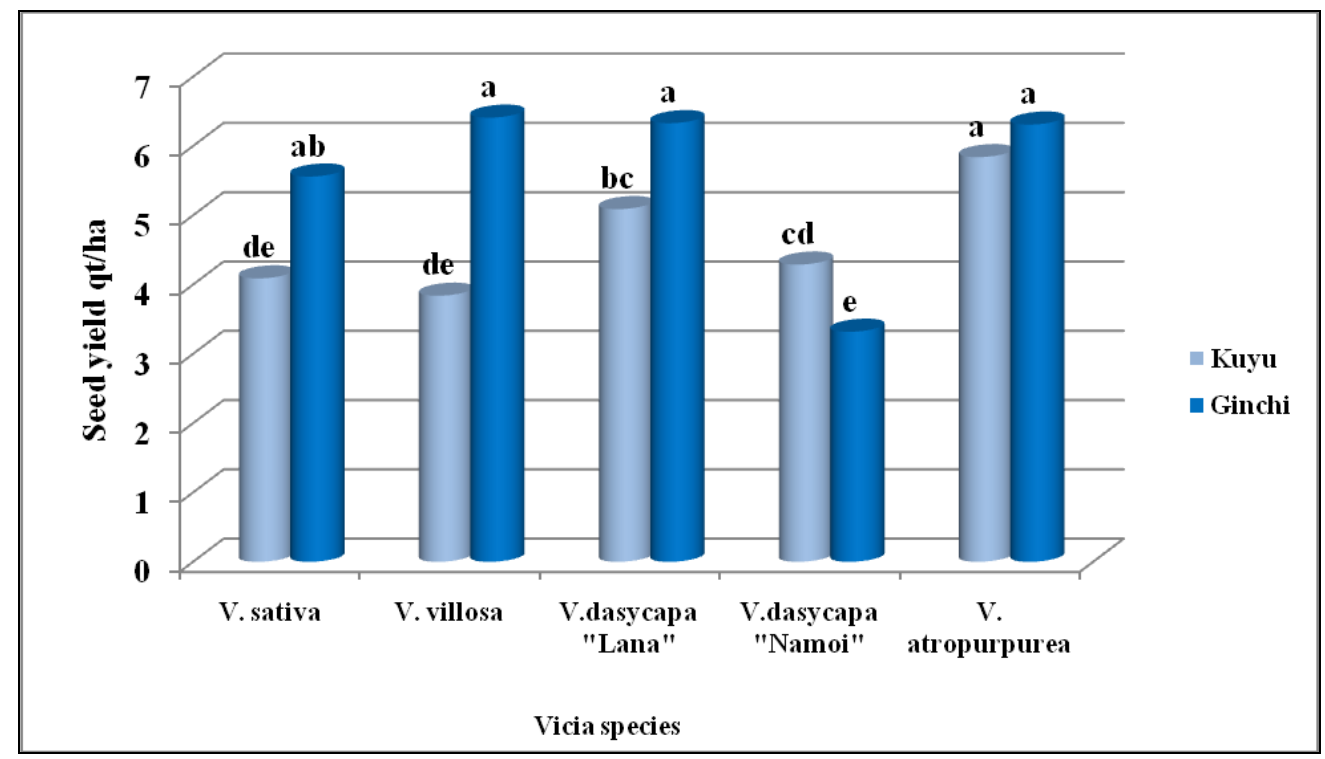

Figure 7. Species by location interaction for seed yield of vicia species

\section{Conclusion}

The combined analysis of variance showed that drainage methods, vicia species, and locations had significant differences for mean plant height, DM yield and seed yield. The results revealed that drainage method by year, species by location, location by year and species by year by location interaction effects were significant for at least one of the measured agronomic trait. The $\mathrm{CB}$ and $\mathrm{RF}$ showed increments for plant height, DM yield and seed yield when compared with FB. Similarly, CB showed increment for plant height, DM yield and seed yield over the RF drainage method. The highest DM yield was recorded for $V$. villosa followed by $V$. dasycarpa "Lana", $V$. atropurpurea and $V$. dasycarpa "Namoi" while $V$. sativa gave the lowest DM yield under different drainage methods. Similarly, the highest seed yield was recorded for $V$. atropurpurea followed by $V$. dasycarpa "Lana", $V$. villosa and $V$. sativa while $V$. dasycarpa "Namoi" gave the lowest seed yield under different drainage methods. Higher plant height, better DM and seed yields were obtained at Ginchi when compared with Kuyu and in 2012 when compared with in 2013 cropping season indicating that locations and years affects the measured agronomic traits of vicia species under different drainage methods. Generally, the species respond differently for measured agronomic traits under different drainage methods. Therefore, V. villosa, V. dasycarpa "Lana" and V. atropurpurea showed better performance in terms of plant height, DM yield and seed yield under different drainage methods on vertisol at Kuyu and Ginchi in the central highlands of Ethiopia.

\section{REFERENCES}

[1] Abate T. and Mohamed-Saleem M.A. (1992). Cropping systems for vertisols of the Ethiopian highlands. In: Reports and papers on the management of vertisols (IBSRAM/AFRICA LAND). Network document 1. IBSRAM (International Board for soil research and development), Nairobi, Kenya.

[2] Abate T., Mohamed-Saleem M.A., Tekalign M., Alemu T. and Miiressa D. (1993). Grain, fodder, and residue management. In: Tekalign M., Abiya A., Srivastava K.L. and Asgelil D. (eds.). Improved management of vertisol for sustainable crop-livestock production in the Ethiopian highlands. The joint vertisol project, Addis Ababa, Ethiopia.

[3] Abiye A. and Ferew K. (1993). Grain, fodder, and residue management. In: Tekalign M., Abiya A., Srivastava K.L. and Asgelil D. (eds.). Improved management of vertisol for sustainable croplivestock production in the Ethiopian highlands. The joint vertisol project, Addis Ababa, Ethiopia. 
[4] Abiye A., Muhamed-Saleem M.A. and ElWakeel A. (1995). Soil water dynamics under cereal and forage legume mixtures on drained Vertisols in the Ethiopian highlands. Agric. Water Manage.

[5] Adjei A.I., Dapaah S.O. and Dontwi I.K. (2010). Predicting the best genotype from analysis of genotype by environment interaction. European J. Sci. Res. 45(1): 128-135.

[6] Ali Y.A. (1992). Nitrogen transformation in some Ethiopian highland vertisols. $\mathrm{PhD}$ thesis, University college of Wales, Aberystwth, UK.

[7] Banziger M. and Edmeades G.O. (1997). Predicted productivity gains from breeding maize under stressed vs. non-stressed conditions. In: JK. Ransom, AFE. Palmer, BT. Zambezi, ZO. Mduruma, SR. Waddigton, KV. Pixley and DC. Jewell (eds.). Maize productivity gains through research and technology dissemination: Proceedings of the $5^{\text {th }}$ eastern and Southern Africa regional Maize Conference, held in Arusha, Tanzania, 3-7 June 1996. Addis Ababa, Ethiopia, CIMMYT.

[8] Berhanu D. (1985). The vertisols of Ethiopia, their characteristics, classification and management. In: Fifth meeting of the eastern Africa sub-committee for soil correlation and land evaluation, Wad Medani, Sudan, 5-10 December 1983. World soil resources report No. 56. FAO (food and Agricultural Organization), Rome.

[9] Bull T.A. (1988). Agro-ecological assessment of Ethiopian vertisols. In: Jutzi SC, Haque I, McIntire J and Stares JES (eds.). Management of vertisols in Sub-Saharan Africa. Proceedings of a conference held at ILCA, Addis Ababa, Ethiopia, 31 August-4 September 1987. ILCA.

[10] Ceccarelli S. (1997). Adaptation to low/high input cultivation. Adaptation in plant breeding (Tigerstedt, P.M.A., ed), Kluwer Academic publisher, The Netherlands.

[11] Crossa, J. (1990). Statistical analysis of multi-location trials. Advances in Agronomy. 44: 55-85.

[12] Delacy I.H., Basford K.E., Cooper M. and Bull J.K. (1996). Analysis of multi-environment trials- an historical perspective. Plant Adaptation and Crop Improvement. Eds. M. Cooper and G. L. Hammer. CAB international.

[13] Desta B. (1982). Diagnosis of phosphorus deficiency in Ethiopian soils. Soil Science Bulletin No. 3. IAR (Institute of Agricultural Research), Addis Ababa, Ethiopia.

[14] Efrem B., Tesfaye T. and Demisse M. (1996). Performance of duram wheat genotypes under two naturally waterlogged highland vertisols of Ethiopia. Eth. J. Agri. Sci. 15:44-54.

[15] Ethiopian Institute of Agricultural Research (EIAR). (2005). Holetta Agricultural Research Center/ HARC/ progress report 2005/06. EIAR/HARC.

[16] Gemechu K. (2012). Genetic potential and limitations of Ethiopian chickpea (Cicer arietinumal) germplasm for improving attributes of symbiotic nitrogen fixation, phosphorus uptake and use efficiency, and adzuki been beetle (Callosobruchus chinensis L.) resistance. PhD. Thesis Addis Ababa University faculty of life science, Ethiopia.

[17] Gemechu K. and Musa J. (2002). Comparison of three secondary traits as determinants of grain yield in faba bean on waterlogged vertisols. J. Genet. \& Breed. 56:317-326.

[18] Gemechu K., Belay A. and Musa J. (2001). Efficiency of drained selection environments for improving grain yield in faba bean under undrained target environments on vertisols. Kluwer Acadamic Publishers. Printed in the Netherlands. Euphytica. 122:279-285.

[19] Getachew A., Abraham F., Gemechu K. and Mussa J. (2007). Chickpea varietal responses to drainage on vertisol of Ginchi highlands of Ethiopia. Ethiopian Society of Soil Science, Ethiopian Journal of Natural Resources. 2: 191-207.

[20] Getachew A. and Amare G. (2004). Effects of drainage and genotype on yield and some yield components of faba bean on a highland vertisol in Ethiopia. Ethiopian Jornal of Natural Resources 6(2): 167-182.

[21] Getachew A., Hailu B., Workeneh N. and Gezahegn A. (1993). A survey of farming systems of vertisols areas of the Ethiopian highlands. In: Tekalign Mamo, Abiye Astatke, KL. Srivastana and Asgelil Dibabe (eds.). Improved management of vertisols for sustainable crop and livestock production in the Ethiopian highlands: Synthesis report 1986-92. Technical committee of the joint vertisol project, Addis Ababa, Ethiopia. 
[22] Getachew A., Jutzi S.C., Abate T. and McIntire J. (1988). Economic evaluation of improved vertisol drainage for food crop production in the Ethiopian highlands. In: SC. Jutzi, L. Haque, J. McIntire and JE. Stares (eds.). Management of vertisol in Sub-Saharan Africa. Proceedings of a conference, 31 Aug. 4 Sept. 1987, ILCA, Addis Ababa.

[23] Getachew A. and Woldeyesus S. (2012). Drainage, sowing date and variety effects on chickpea grown on a vertisol in Ethiopia, Archives of Agronomy and Soil Science, 58(1): 101-113.

[24] Getnet A. and Ledin I. (2001). Effect of variety, soil type and fertilizer on the establishment, growth, forage yield and voluntary intake by cattle of oats and vetches cultivated in pure and stands and mixtures. Animal feed science and technology. 92 (2001): 95-111.

[25] Haque I., Lupwayi N.Z. and Luyindula N. (1996). Inoculation and phosphorus effects on Desmodium intortum and Sesbania sesban in the Ethiopian highlands. Agric. Ecosyst. Environ. 56:165.72.

[26] Hiruy B. (1986). The effect of drainage systems, drainage spacing and fertilizer on seed yield and other characters of wheat, tef and chickpea on heavy clay soils of Ginchi. Ethiopia. J. of Agri. Sci. 8:85-94.

[27] Institute of Agricultural Research (IAR). (1986). Department of animal science pasture and forage team progress report, April $1984 \mathrm{t}$ o march 1985 Addis Ababa.

[28] Kang M.S. (2004). Breeding: Genotype-by-environment interaction. In R.M. Goodman (ed.) Encyclopedia of plant and crop science. Marcel-Dekker, New York.

[29] Kebede G., Feyissa F., Assefa G., Mengistu A., Tekletsadik T. and Minta M. (2016). Determination of appropriate fertilizer rate for forage and seed yields of fodder beet (Beta vulgaris) in the central highland areas of Ethiopia. Acad. Res. J. Agri. Sci. Res. 4(5): 174-183.

[30] Mesfin A. (1981). Soil burning in Ethiopia. Ethiopian Journal of Agricultural Sciences 3(1): $57-$ 74.

[31] Mesfin A. and Jutzi S.C. (1989). The joint project on improved management and utilization of dark clay soils in Ethiopia, retrospect and prospects. Pages 385-398 in vertisol management in Africa. International Broad for soil research and management (IBSRAM), proceedings No. 9, Bangkok.

[32] Muhamed-Saleem M.A. and Abiye A. (1996). Options to intensify cropland use for alleviating smallholder energy and protein deficiencies in the East African highlands. Field Crops Res. 48:177-184.

[33] Pillai U.P. and McGarry D. (1999). Structure repair of a compacted Vertisol with wet-dry cycles and crops. Soil Science Society of America Journal. 63: 201-210.

[34] Simmonds N.W. (1991). Selection for local adaptation in a plant breeding programme. Theor. Appl. Genet. 82: 363-367.

[35] Sinebo W. (2005). Trade off between yield increase and yield stability in three decades of barely breeding in a tropical highland environment. Field Crop Res. 92:35-52.

[36] Singh B.D. (1990). Plant breeding: Principles and methods. Kalyani Publishers, New DelhiLudhiana, India.

[37] Wenke J.F. and Grant C.D. (1994). The index of self-mulching behavior in soils. Australian Journal of Soil Research. 32: 201- 211. 